\title{
A cerebrovascularis betegségekből eredő, idő előtti halálozás egyenlőtlenségei Európában 1990 és 2014 között
}

\author{
Németh Noémi drd. ${ }^{1,2}$. Endrei Dóra dr. ${ }^{1,2}$ - Horváth Lilla ${ }^{1,2}$ \\ Elmer Diána ${ }^{1,2}$ - Csákvári Tímea ${ }^{1,2}$ - Pónusz Róbert ${ }^{1,2}$ \\ Szapáry László dr. ${ }^{3}$. Boncz Imre dr. ${ }^{1,2}$ \\ ${ }^{1}$ Pécsi Tudományegyetem, Egészségtudományi Kar, Egészségbiztosítási Intézet, Pécs \\ ${ }^{2}$ Pécsi Tudományegyetem, Egészségtudományi Kar, \\ Real World \& Big Data Egészség-gazdaságtani Kutatóközpont, Pécs \\ ${ }_{3}^{3}$ Pécsi Tudományegyetem, Általános Orvostudományi Kar, Klinikai Központ, Neurológiai Klinika, Pécs
}

Bevezetés: A cerebrovascularis betegségek népegészségügyi szempontból jelentősek, világszerte a vezető halálokok között szerepelnek, és a rokkantság egyik fó okát képezik.

Célkitüzés: Vizsgálatunk célja a cerebrovascularis betegségekből eredő, idő előtti halálozás hazai és nemzetközi adatainak elemzése régiónkénti bontásban a 45-59 éves korcsoportban.

Módszerek: Retrospektív, kvantitatív elemzés keretében vizsgáltuk a cerebrovascularis betegségekből eredő, korspecifikus, 1990 és 2014 közötti halálozást az Egészségügyi Világszervezet (WHO) Európai Régióján belül kiválasztott nyugat-európai $(\mathrm{n}=17)$, kelet-európai országokban $(\mathrm{n}=10)$ és a volt Szovjetunió utódállamaiban $(\mathrm{n}=15), 100000$ fơre vetítve, a WHO Európai Halálozási Adatbázisának adatai alapján. Leíró statisztikai módszereket, idősoros kimutatást, Kruskal-Wallis-próbát alkalmaztunk.

Eredmények: A cerebrovascularis betegségekből eredő, 100000 fớre vetített korspecifikus halálozás a nyugat-európai országokban volt a legalacsonyabb (férfiak: 1990: 35,14, 2014: 14,31; nők: 1990: 21,11, 2014: 8,76) és a Szovjetunió utódállamaiban a legmagasabb (férfiak: 1990: 134,19; 2014: 91,13; nók: 1990: 83,62, 2014: 41,83) (p<0,05). A kelet-európai és a nyugat-európai országok, valamint a nyugat-európai országok és a Szovjetunió utódállamainak korspecifikus, cerebrovascularis halálozása között szignifikáns különbséget találtunk mindkét nemben (1990, 2004, 2014: p<0,05). A cerebrovascularis betegségek korspecifikus standardizált halálozása 1990 és 2014 között a nyugateurópai országokban (férfiak: $-59,28 \%$, nők: $-58,29 \%$ ) csökkent a legnagyobb mértékben, melyet a vizsgált keleteurópai országok (férfiak: $-54,14 \%$, nők: $-57,53 \%$ ), majd a Szovjetunió utódállamai (férfiak: -32,09\%, nők: -49,97\%) követtek.

Következtetések: A korspecifikus, cerebrovascularis halálozás a férfiak és a nők körében egyaránt csökkent az egyes régiókban. Magyarországon a nyugat-európai átlagnál jobban, 62,2\%-kal csökkent a férfiak és 59,1\%-kal a nók korai cerebrovascularis halálozása 1990 és 2014 között.

Orv Hetil. 2021; 162(4): 144-152.

Kulcsszavak: cerebrovascularis betegségek, idő előtti halálozás, korspecifikus mortalitás

\section{Inequalities in premature mortality due to cerebrovascular disease in Europe between 1990 and 2014}

Introduction: Cerebrovascular diseases are a significant public health concern, they are among the leading causes of death worldwide and one of the major causes of disability.

Objective: Our aim was to analyse national and international data regarding premature, cerebrovascular disease mortality per region in the $45-59$ age group.

Methods: We performed a retrospective, quantitative analysis on age-specific, premature cerebrovascular disease mortality between 1990 and 2014 per 100000 population on data derived from the World Health Organisation, European Mortality Database on Western European $(n=17)$, Eastern European $(n=10)$ countries, and countries of the former Soviet Union $(\mathrm{n}=15)$. Descriptive statistics, time series analysis and Kruskal-Wallis test were performed. 
Results: Age-related, cerebrovascular disease mortality per 100000 population was the lowest in Western European countries (males: 1990: 35.14, 2014: 14.31; females: 1990: 21.11, 2014: 8.76), and the highest in former Soviet Union countries (males: 1990: 134.19; 2014: 91.13; females: 1990: 83.62, 2014: 41.83) (p<0,05). Significant differences were found in age-specific, cerebrovascular disease mortality in both sexes between Eastern and Western European countries and former Soviet Union countries (1990, 2004, 2014: p<0.05). Between 1990 and 2014, agespecific, standardized cerebrovascular disease mortality showed the biggest decrease in Western European countries (males: $-59.28 \%$, females: $-58.29 \%$ ) followed by Eastern European (males: $-54.14 \%$, females: $-57.53 \%$ ) and former Soviet Union countries (males: $-32.09 \%$, females: $-49.97 \%$ ).

Conclusions: Age-specific, cerebrovascular disease mortality decreased in both sexes in all regions analysed. Hungary was found to have seen a decrease above the Western European average, premature cerebrovascular mortality decreased by $62.2 \%$ in males and $59.1 \%$ in females between 1990 and 2014 .

Keywords: cerebrovascular diseases, premature mortality, age-specific mortality

Németh N, Endrei D, Horváth L, Elmer D, Csákvári T, Pónusz R, Szapáry L, Boncz I. [Inequalities in premature mortality due to cerebrovascular disease in Europe between 1990 and 2014]. Orv Hetil. 2021; 162(4): 144-152.

(Beérkezett: 2020. június 30.; elfogadva: 2020. augusztus 3.)

\section{Rövidítések:}

$\mathrm{BNO}=$ betegségek nemzetközi osztályozása; $\mathrm{SD}=$ standard deviáció; SDR = (standardized death rate) standardizált halálozási arányszám; $\mathrm{WHO}=$ (World Health Organization $)$ Egészségügyi Világszervezet

A cerebrovascularis betegségek világviszonylatban a második helyen állnak a halálokok között, s Európában is kiemelt jelentőséggel bírnak [1,2]. A cerebrovascularis betegségek a rokkantság egyik fó okát képezik világszerte, ami jelentős terhet ró az egyénre és a társadalomra [1,3-6]. Az agyi érbetegségek az aktív népességet is érintik, ezáltal korai halálozást kiváltva, ami a 35-64 éves korosztályban jelentős növekedést mutat az Egyesült Államokban [1].

Az idő előtti halálozásnak standard definíciója nincs, mivel függ az adott országban a születéskor várható átlagos élettartamtól, mely területenként eltérő, ezért a "European Cardiovascular Disease Statistics" 2017. évi kiadásában megkülönböztetnek 75 éves kor előtti és 65 éves kor előtti halálozást. Európában a 75 év alatti férfiaknál a stroke a harmadik, a nóknél a második leggyakoribb halálok. A 65 év alatti nők esetében az emlőrákkal egyetemben a leggyakoribb halálokot képezi, ebben a korcsoportban a férfiak esetében a harmadik leggyakoribb halálok az ischaemiás szívbetegségből és a tüdőrákból eredő, idő előtti halálozásokat követve. Az idő előtti halálozás csökkenthető a hatékony egészségügyi ellátás biztosításával, valamint a befolyásolható rizikófaktorok kiiktatásával, kezelésével [7]. A stroke tekintetében a legfontosabb befolyásolható kockázati tényezők közé sorolják a dohányzást, a túlzott alkoholfogyasztást, az elhízást, az ülő életmódot, a zsíranyagcsere zavarait, a magas vérnyomást és a cukorbetegséget [8-11]. A betegség fontos kockázati tényezói között kiemelendő a pitvarfibrilláció, mely az időskori ischaemiás stroke-ok egyik leg- fontosabb oki tényezője [8, 12-15]. A stroke kialakulásának megelőzésében meghatározó szerepe van többek között a dohányzás visszaszorításának, a megfelelő táplálkozásnak és az Egészséges Városok Programnak, valamint a fent említett rizikófaktorok korábbihoz képest jóval hatékonyabb gyógyszeres kezelési lehetőségének [10, 13, 15-17]. Az akut stroke-hoz kapcsolódó korai és késői halálozás alakulásának tekintetében hangsúlyozandó a rekanalizációs kezeléseket az utóbbi években érintő jelentős változások szerepe, elsősorban a nagyérelzáródások katéteres kezelési lehetőségének egyre szélesebb körü terjedése [18, 19].

A stroke gyakoriságával, a betegség kimenetelével, területi egyenlőtlenségeivel több vizsgálat foglalkozott, köztük a MONICA-tanulmány, mely Magyarországra nézve rendkívül kedvezőtlen eredményeket mutatott. A kedvezőtlen magyarországi adatok hátterében adattorzítás figyelhető meg. Az eredményeket befolyásolhatja, hogy több európai ország - köztük Románia és Ukrajna - statisztikai adatok hiánya okán nem került be a vizsgálatba. Európán belül a stroke okozta halálozás tekintetében jelentős különbségeket írtak le [20-24]. Ugyanakkor a kimeneteli adatok szegényesek, a különbségek okainak feltárásához további vizsgálatok szükségesek [20].

Elemzésünk célja a cerebrovascularis betegségekből eredő, idő előtti halálozás tekintetében a hazai és a nemzetközi halálozási adatok bemutatása, összehasonlítása régiónkénti bontásban a 45-59 éves korcsoportban.

\section{Adatok és módszerek}

Retrospektív, kvantitatív kutatás keretében a cerebrovascularis betegségekből eredő, idő előtti, 100000 forre vetített standardizált halálozást vizsgáltuk a 45-59 éves korcsoportban. Elemzésünk a WHO Európai Régiójába tartozó, általunk kiválasztott nyugat-európai országokra 
(n = 17; Ausztria, Belgium, Dánia, Finnország, Franciaország, Németország, Görögország, Hollandia, Írország, Luxemburg, Norvégia, Olaszország, Egyesült Királyság, Portugália, Svédország, Spanyolország, Svájc), kelet-európai országokra ( $\mathrm{n}=10$; Bulgária, BoszniaHercegovina, Cseh Köztársaság, Horvátország, Lengyelország, Magyarország, Románia, Szerbia, Szlovákia, Szlovénia), valamint a Szovjetunió utódállamaira ( $\mathrm{n}=$ 15; Azerbajdzsán, Észtország, Fehéroroszország, Grúzia, Kazahsztán, Kirgizisztán, Lettország, Litvánia, Moldovai Köztársaság, Oroszország, Örményország, Tádzsikisztán, Türkmenisztán, Ukrajna, Üzbegisztán) terjedt ki. Vizsgálatunkat az említett országokból származó adatok elérhetőségének függvényében az adathiány mérséklésének figyelembevételével az 1990 és 2014 közötti időszakra vonatkozóan végeztük, különös tekintettel az 1990-es, 2004-es, 2014-es évekre. A kelet-európai országokban és a szovjet utódállamokban 1990 után jelentős társadalmi változások történtek, 2004-től pedig a kelet-európai országok többsége csatlakozott az Európai Unióhoz.

Vizsgáltuk a 45-59 éves korcsoportban a cerebrovascularis betegségek okozta, standardizált halálozásból eredő, nemek közti különbségeket, területi egyenlőtlenségeket, időbeli és térbeli változásokat az egyes országok besorolásával létrehozott fenti csoportokban, valamint az egyes csoportok között.

Adataink az Egészségügyi Világszervezet (WHO) Európai Halálozási Adatbázisából származnak, a következő indikátorra vonatkozóan: „SDR (45-59), cerebrovascular diseases, per 100 000". Stroke-halálozáson a WHO a BNO 10. revíziója szerinti I60-I69 haláloki diagnózis alkalmazását érti. A nyers halálozási mutatók a standard (referencia) európai népesség korcsoportos összetételére vannak standardizálva. Az adatbázis adatait az egyes országok nyilvántartási rendszereiból származó adatok képezik. Az elemzésünk során felhasznált adatok a legutolsó, 2019. október 17-i adatbázis-frissítésnek felelnek meg.

Elemzéseinket az MS Excel 2007 (Microsoft Corporation, Redmond, WA, Amerikai Egyesült Államok [USA]) és az SPSS 22.0 (IBM Corporation, Armonk, NY, USA) programmal végeztük. Leíró statisztikai módszerek (átlag, átlag megbízhatósági tartomány 95\%-os valószínúségi szinten, szórás) alkalmazása mellett idősoros kimutatást, matematikai statisztikai próbaként Kruskal-Wallis-próbát végeztünk $(\mathrm{p}<0,05)$. A teszt elvégzése során annak megértésére, hogy pontosan mely régiók különböznek egymástól, a páronkénti összehasonlítás (pairwise comparisons) funkciót használtuk. A KruskalWallis-próba mellett a vizsgált változók nem normális eloszlása $(\mathrm{p}<0,05)$ miatt döntöttünk.

\section{Eredmények}

A férfiak cerebrovascularis betegségekből eredő, korspecifikus halálozása a Szovjetunió utódállamaiban (134,19;
$\mathrm{SD}=32,95 ; \min .=65,67$ : Örményország; max. = 186,19: Kirgizisztán) átlagosan közel 4-szer, a kelet-európai országokban $(105,05 ; \mathrm{SD}=33,13 ; \mathrm{min} .=69,5$ : Bosznia-Hercegovina; max. = 157,14: Bulgária) pedig 3-szor volt magasabb, mint a nyugat-európai országokban $(35,14 ; \mathrm{SD}=14,29 ;$ min. = 15,88: Svájc; $\max .=$ 77,17: Portugália) 100000 före vetítve 1990-ben. A férfiak körében a cerebrovascularis betegség okozta korai halálozás 2004-ben a Szovjetunió utódállamaiban $(147,79 ;$ SD = 60,40; min. = 56,55: Tádzsikisztán; max. = 242,03: Kirgizisztán) átlagosan 7-szer, a kelet-európai országokban $(78,22 ; \mathrm{SD}=36,84 ; \mathrm{min} .=37,38:$ Cseh Köztársaság; max. = 136,05: Románia) 3,7-szer volt magasabb, mint a nyugat-európai országokban (21,16; $\mathrm{SD}=8,27 ; \min .=10,98:$ Svájc; $\max .=43,58$ : Portugália). A férfiak korai, cerebrovascularis betegségekből eredő halálozása 2014-ben a Szovjetunió utódállamaiban $(91,13 ; \mathrm{SD}=38,24 ;$ min. = 28,49: Észtország; max. = 172,8: Kirgizisztán) 6,4-szer, a kelet-európai országokban $(48,18 ;$ SD = 25,16; min. = 15,85: Szlovénia; max. = 101,02: Bulgária) pedig 3,4-szer volt magasabb, mint a nyugat-európai országokban $(14,31 ; \mathrm{SD}=5,65$; min. =7,73: Norvégia; max. = 26,82: Görögország) 100000 före vetítve. A 45-59 éves férfiak cerebrovascularis betegségekból eredő halálozásában a kelet-európai, a nyugat-európai országok és a Szovjetunió utódállamai között szignifikáns különbséget találtunk $(\mathrm{p}<0,001)$ (1. ábra).

A nook tekintetében elmondható, hogy 1990-ben átlagosan a Szovjetunió utódállamaiban 4-szer $(83,62 ;$ SD = 21,53; min. = 49,37: Észtország; $\max .=117,98$ : Kirgizisztán), a kelet-európai országokban (56,26; SD = 17,31; min. = 31,58: Szlovénia; max. = 77,52: Bulgária $)$ több mint 2,5-szer magasabb volt a korspecifikus, standardizált halálozás, mint a nyugat-európai országokban $(21,11 ; S D=8,32 ;$ min. $=10,05:$ Svájc $; \max .=46$ : Portugália). A nők cerebrovascularis betegségekből eredő, korai halálozása 2004-ben a Szovjetunió utódállamaiban 6,2-szer $(83,79 ;$ SD = 38,16; min. = 34,61: Litvánia; max. = 158,05: Kirgizisztán), a kelet-európai országokban $(40,61 ; S D=22,01 ;$ min. = 17,05: Cseh Köztársaság; $\max .=79,43$ : Románia) 3-szor volt magasabb, mint a nyugat-európai országokban $(13,44 ; \mathrm{SD}=3,45 ; \mathrm{min}$. =7,41: Svájc; $\max .=20,08$ : Portugália ). A nók cerebrovascularis, standardizált halálozása 2014-ben a Szovjetunió utódállamaiban $(41,83 ; \mathrm{SD}=19,72 ; \min .=14,62$ : Észtország; max.: 81,67: Kirgizisztán) 4,8-szor, a keleteurópai országokban $(23,89 ; \mathrm{SD}=10,98 ; \min .=10,49$ : Szlovénia; max. = 46,47: Bulgária) 2,7-szer volt magasabb, mint a nyugat-európai országokban $(8,76 ; \mathrm{SD}=$ 2,69; min. = 1,75: Luxemburg; $\max .=12,61$ : Portugália). A 45-59 éves nők cerebrovascularis betegségből eredő halálozásában a kelet-európai, a nyugat-európai országok és a Szovjetunió utódállamai között szignifikáns különbséget találtunk $(\mathrm{p}<0,001)$ (2. ábra).

A férfiak és a nôk esetében is a nyugat-európai és a kelet-európai országok, valamint a nyugat-európai orszá- 


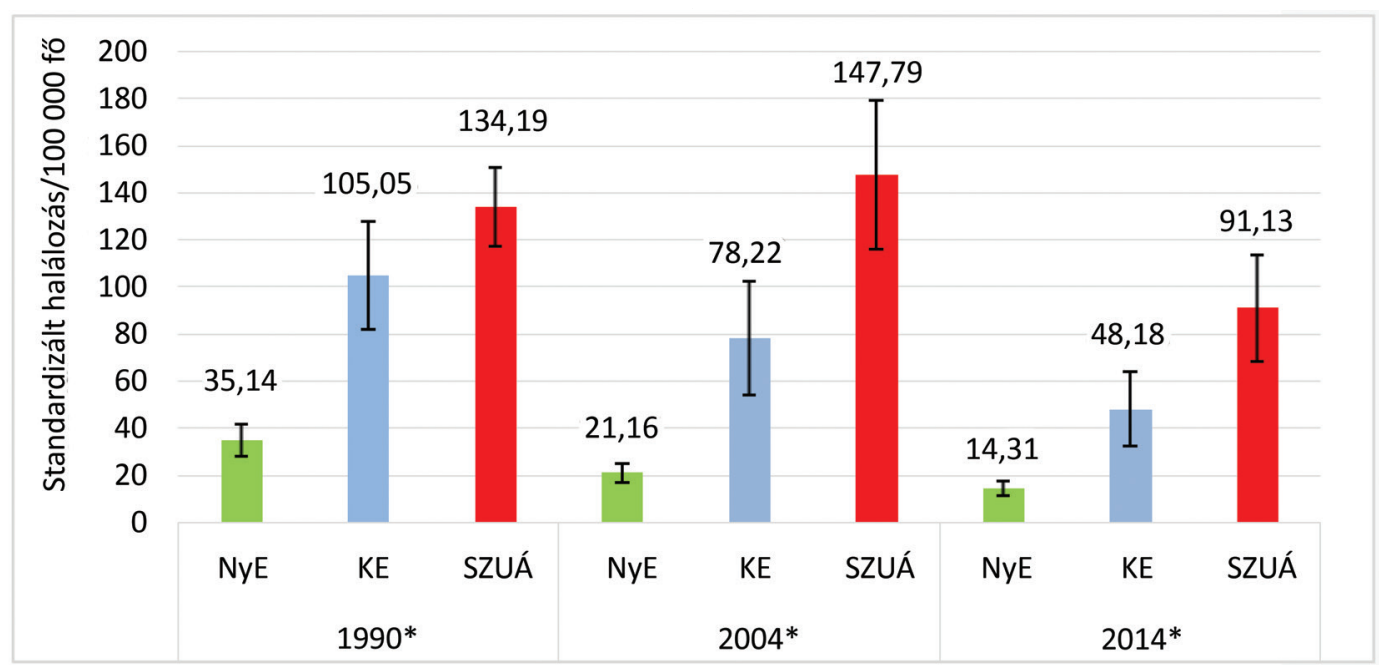

1. ábra

| Cerebrovascularis betegségekból eredő, standardizált halálozás a 45-59 éves férfiak körében 1990-ben, 2004-ben és 2014-ben (95\% CI) $\left[{ }^{*} \mathrm{p}<0,001\right.$, Kruskal-Wallis-próba $]$

$\mathrm{CI}=$ konfidenciaintervallum; $\mathrm{KE}=$ Kelet-Európa $\mathrm{NyE}=$ Nyugat-Európa; SZUÁ = a Szovjetunió utódállamai

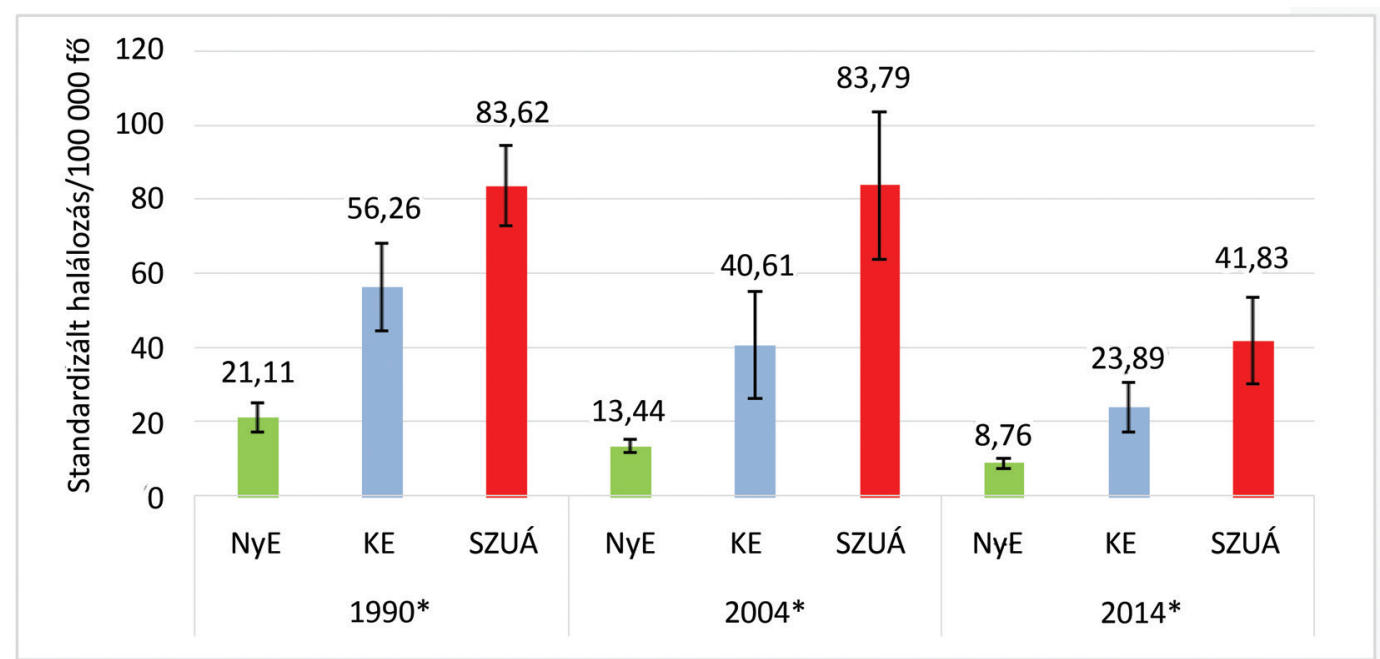

2. ábra $\quad$ Cerebrovascularis betegségekből eredő, standardizált halálozás a 45-59 éves nők körében 1990-ben, 2004-ben és 2014-ben (95\% CI) $\left[{ }^{*} \mathrm{p}<0,001\right.$, Kruskal-Wallis-próba $]$

$\mathrm{CI}=$ konfidenciaintervallum; $\mathrm{KE}=$ Kelet-Európa; $\mathrm{NyE}$ = Nyugat-Európa; SZUÁ = a Szovjetunió utódállamai

gok és a Szovjetunió utódállamai között találtunk szignifikáns különbséget a korspecifikus, cerebrovascularis halálozásban az 1. táblázatban látható évek (1990, 2004, 2014 ) vonatkozásában, Kruskall-Wallis-próbán belül páronkénti összehasonlítással $(\mathrm{p}<0,05)$. Egyik nem tekintetében sem találtunk szignifikáns kapcsolatot a kelet-európai országok és a Szovjetunió utódállamainak halálozása között (p>0,05) (1. táblázat).

A 3. ábra szemlélteti, hogy a férfiak korra standardizált, cerebrovascularis betegségekből eredő halálozása 1990 és 2014 között átlagosan a nyugat-európai országokban 59,28\%-kal csökkent, amit a vizsgált kelet-európai országok 54,14\%-os csökkenéssel, majd a Szovjetunió utódállamai 32,09\%-os csökkenéssel követtek. A férfiak korspecifikus, cerebrovascularis betegségekből
1. táblázat |Az egyes országcsoportok Kruskal-Wallis-próbával történő pá ronkénti összehasonlításának (pairwise comparisons) szignifikanciaszintjei az egyes vizsgált években

\begin{tabular}{llll}
\hline & $\begin{array}{c}\text { Kelet-Európa vs. } \\
\text { Nyugat-Európa }\end{array}$ & $\begin{array}{c}\text { Kelet-Európa vs. } \\
\text { Szovjetunió }\end{array}$ & $\begin{array}{c}\text { Nyugat-Európa vs. } \\
\text { Szovjetunió }\end{array}$ \\
\hline Férfiak & $\mathrm{p}=0,004$ & $\mathrm{p}=0,957$ & $\mathrm{p}<0,001$ \\
\hline 1990 & $\mathrm{p}=0,006$ & $\mathrm{p}=0,353$ & $\mathrm{p}<0,001$ \\
2004 & $\mathrm{p}=0,007$ & $\mathrm{p}=0,231$ & $\mathrm{p}<0,001$ \\
2014 & & & \\
\hline Nők & $\mathrm{p}=0,012$ & $\mathrm{p}=0,315$ & $\mathrm{p}<0,001$ \\
\hline 1990 & $\mathrm{p}=0,007$ & $\mathrm{p}=0,304$ & $\mathrm{p}<0,001$ \\
2004 & $\mathrm{p}=0,005$ & $\mathrm{p}=0,417$ & $\mathrm{p}<0,001$ \\
\hline
\end{tabular}


eredő halálozása a nyugat-európai országokban összességében véve 17,85\%-kal csökkent 1990 és 1995 között. A 45-59 éves férfiak agyi érrendszeri betegségekből eredő halálozása a nyugat-európai országokban 52,36\%-kal csökkent 1996-tól a vizsgálati periódusunk végéig. A férfiak korspecifikus, cerebrovascularis halálozása a keleteurópai országokban összességében 6,08\%-kal növekedett 1990 és 1994 között, majd 1994 és 1995 között 7,49\%-kal csökkent. A férfiak 100000 före vetített, cerebrovascularis betegségekből eredő, idő előtti halálozása enyhén emelkedett (+4,19\%) 1995 és 1997 között, majd kisebb ingadozásokat leszámítva a vizsgálati periódus végéig csökkent $(-55,15 \%)$. A férfiak korspecifikus, cerebrovascularis halálozása a Szovjetunió utódállamaiban összességében 25,78\%-kal növekedett 1990 és 1995 között, ezt követően 1995 és 1998 között csökkent $(-16,94 \%)$, majd 1998 és 2005 között összességében ismételten emelkedett $(+10,17 \%)$. A 45-59 éves férfiak cerebrovascularis betegségek okozta halálozása a Szovjetunió utódállamaiban 40,99\%-kal csökkent 2005-től elemzési periódusunk végéig (3. ábra).

A nôk korspecifikus, cerebrovascularis betegségekből eredő, standardizált halálozása 1990 és 2014 között a nyugat-európai országokban $(-58,29 \%)$ csökkent a legnagyobb mértékben hasonlóan a férfiakhoz, melyet a vizsgált kelet-európai országok $(-57,53 \%)$, majd a Szovjetunió utódállamai követtek $(-49,97 \%)$. A nők korspecifikus, cerebrovascularis halálozása a nyugat-európai országokban 23,72\%-kal csökkent 1990 és 1997 között, majd 1997-től 1999-ig minimálisan, 6,32\%-kal növekedett. A 45-59 éves nők cerebrovascularis halálozása a nyugat-európai országokban összességében véve 48,57\%-kal csökkent 1999-től az elemzett periódus végéig. A nők cerebrovascularis betegségekből eredő, korspecifikus halálozása a kelet-európai országokban 9,17\%kal csökkent 1990 és 1995 között, majd 4,83\%-kal növekedett 1995 és 1998 között. A 45-59 éves keleteurópai nő́k cerebrovascularis betegségek okozta halálozása 55,4\%-kal, szinte folyamatosan csökkent 1998-tól az elemzett időszak végéig. A nók agyi érrendszeri betegségekből eredő, idő előtti halálozása a Szovjetunió utódállamaiban $25,42 \%$-kal növekedett a vizsgált periódus elejétől 1994-ig folyamatosan, majd 1994 és 1999 között 17,43\%-ot csökkent. A nők idő előtti, standardizált, cerebrovascularis betegségekből eredő halálozása a Szovjetunió utódállamaiban 5,75\%-kal növekedett 1999 és 2002 között, majd 2002 és 2004 között 8,49\%-ot csökkent. A nók korspecifikus, cerebrovascularis halálozása a Szovjetunió utódállamaiban minimálisan, 3,28\%kal növekedett 2004 és 2005 között, majd 2005-től 2014-ig folyamatosan csökkent 51,66\%-ot (4. ábra).

$\mathrm{Az}$ 5. ábrán mutatjuk be a férfiak cerebrovascularis betegségekből eredő, korspecifikus halálozásának változását százalékos formában kifejezve. Azerbajdzsán, Írország, Oroszország, Svájc, Szerbia, Szlovákia, Tádzsikisztán, Türkmenisztán adathiány miatt nem szerepel az ábrán. A férfiak esetében az egyes országokban a korspe-

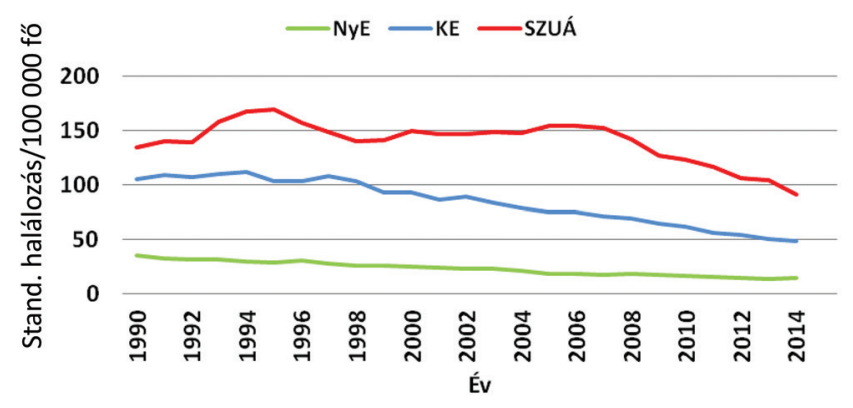

\begin{tabular}{l|l} 
3. ábra & $\begin{array}{l}\text { Cerebrovascularis betegségekből eredő, korra standardizált ha- } \\
\text { lálozás a férfiak körében } 1990 \text { és } 2014 \text { között } \\
\text { KE }=\text { Kelet-Európa; } \mathrm{NyE}=\text { Nyugat-Európa; SZUÁ = a Szovjet- } \\
\text { unió utódállamai }\end{array}$
\end{tabular}

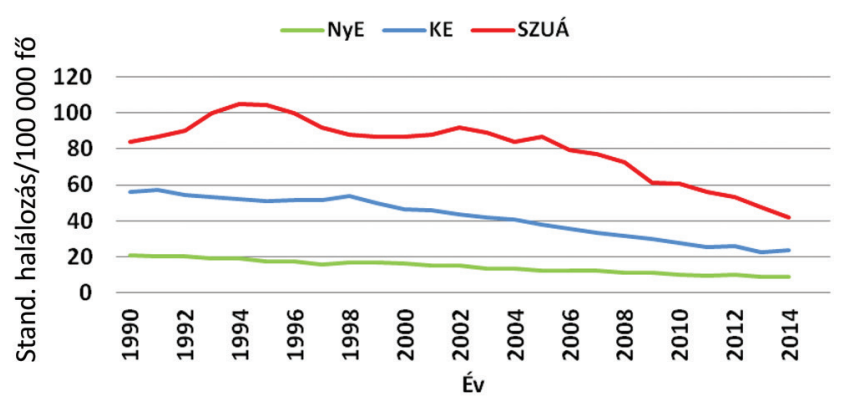

4. ábra $\quad$ Cerebrovascularis betegségekból eredő, korra standardizált halálozás a nők körében 1990 és 2014 között

$\mathrm{KE}=$ Kelet-Európa $; \mathrm{NyE}=$ Nyugat-Európa $;$ SZUÁ $=$ a Szovjet unió utódállamai

cifikus halálozás átlagosan 50,33\%-kal csökkent a teljes vizsgált periódus alatt. A 45-59 éves férfiak cerebrovascularis betegségekből eredő, standardizált halálozásának változása az átlagosnál kedvezőbb volt 21 ország esetén, míg 13 országban az átlagosnál kisebb mértékben csökkent a halálozás. Az utóbbi csoportból 9 ország a Szovjetunió utódállamai közé tartozik, 3 kelet-európai ország és I nyugat-európai ország. A 45-59 éves férfiak körében a cerebrovascularis halálozás valamennyi vizsgált országban csökkent 1990 és 2014 között. A férfiak körében Luxemburg $(-82,12 \%)$ mutatta a legkedvezőbb változást a bázisévhez mérten 2014-re, melyet Észtország $(-80,79 \%)$ és Szlovénia $(-78,66 \%)$ követett. A férfiak idő elótti, cerebrovascularis halálozása a legkisebb mértékben Kirgizisztánban $(-7,19 \%)$ csökkent, melyet Ukrajna $(-12,67 \%)$ és Örményország követett $(-15,64 \%)$. A 4559 éves férfiak agyi érrendszeri betegségek okozta halálozása Magyarországon 62,2\%-kal, azaz a nemzetközi átlagnál jobban csökkent 1990 és 2014 között (5. ábra).

A noók esetében a férfiakhoz hasonlóan ábrázoltuk az egyes országok cerebrovascularis betegségekből eredő, korspecifikus halálozásának 1990 és 2014 közötti változását százalékos formában. Adathiány okán a vizsgált földrajzi eloszlás szerint létrehozott egyes csoportokat tekintve néhány ország (Azerbajdzsán, Irország, Oroszország, Svájc, Szerbia, Szlovákia, Tádzsikisztán, Türk- 


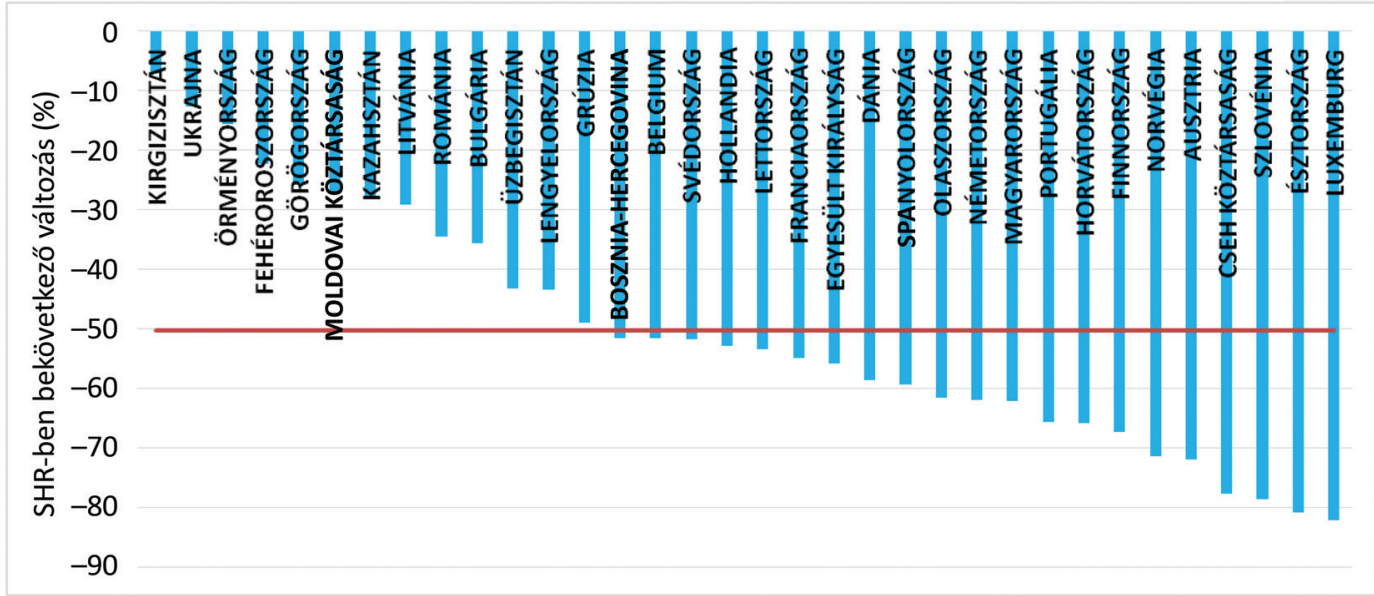

5. ábra $\mid$ A 45-59 éves férfiak körében a cerebrovascularis betegségekből eredő, standardizált halálozás változása 1990 és 2014 között az egyes országokra vonatkozóan

SHR = arány, megoszlás

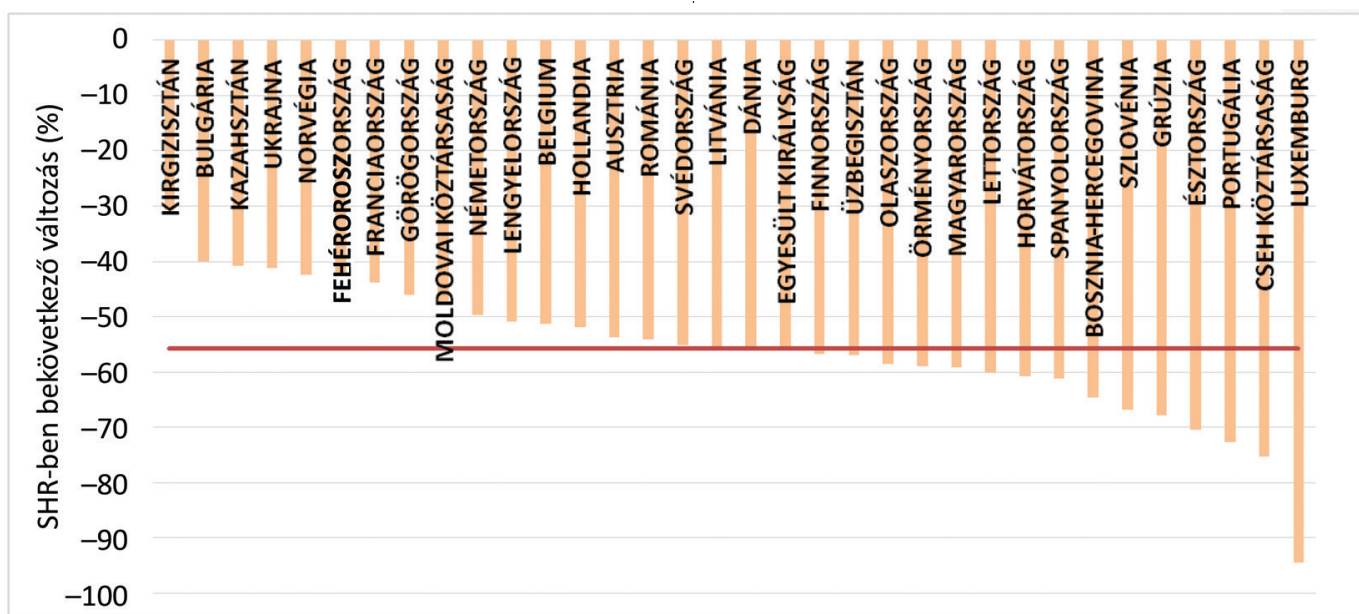

6. ábra $\quad$ A 45-59 éves nők körében a cerebrovascularis betegségekből eredő, standardizált halálozás változása 1990 és 2014 között az egyes országokra vonatkozóan

SHR = arány, megoszlás

menisztán) adatait itt sem tudtuk elemezni. A 45-59 éves nók cerebrovascularis halálozása az egyes országokban átlagosan 55,69\%-kal javult a rendelkezésre álló adatok tükrében. A nôk cerebrovascularis betegségekből eredő, korai halálozását tekintve az átlagosnál kedvezőbb volt a változás 16 ország esetén, míg 18 országban kedvezőtlenebb. Az utóbbi csoportból 9 ország NyugatEurópához, 6 ország a Szovjetunió utódállamaihoz, 3 ország Kelet-Európához tartozik. A nők esetében a cerebrovascularis betegségek okozta, idő előtti, standardizált halálozás valamennyi elemzett ország esetében csökkent a vizsgált periódusban. A nők agyi érrendszeri betegségekből eredő, korspecifikus halálozása tekintetében a legkedvezőbb változást Luxemburg $(-94,43 \%)$ esetében találtuk, a férfiakhoz hasonlóan. A nők cerebrovascularis betegségekből eredő, korspecifikus halálozása Luxemburgot követően a Cseh Köztársaságban $(-75,36 \%)$ és Portugáliában $(-72,59 \%)$ csökkent a legnagyobb mértékben, a férfiak adataitól eltéróen. A 45-59 éves nők cerebrovascularis halálozásában a legkisebb mértékú csökkenést Kirgizisztánban $(-30,78 \%)$ találtuk, a férfiak eredményeihez hasonlóan. A nók korspecifikus, agyi érrendszeri betegségekbőll eredő halálozása Magyarországon a nemzetközi átlagnál jobban, 59,1\%-kal csökkent 1990 és 2014 között (6. ábra).

\section{Megbeszélés}

A WHO Európai Halálozási Adatbázisát használva vizsgáltuk a cerebrovascularis betegségekből eredő, korai halálozást a 45-59 éves korcsoportban a WHO Európai Régiójában.

Vizsgálatunk korlátai között említhetők a WHO-adatbázis hiányosságai (a cerebrovascularis halálozási adatok 
abszolút számokban kifejezhető hiánya, a standardizált halálozási adatok helyenkénti hiánya), melyek torzító hatással lehetnek eredményeinkre. Ezek megfelelőségét befolyásolhatja az egyes országokban alkalmazott halálozási statisztikák különbözősége is. Eredményeink más vizsgálatokkal történő összehasonlítását korlátolta továbbá az egyes régiókba tartozó országok tanulmányonként eltérő csoportosítása, a különböző diagnózisok öszszevont elemzése és országonként eltérő kódolása is. A BNO-10 alkalmazása általános ugyan az európai gyakorlatban, ugyanakkor a kódolásban sok bizonytalanság lehet: problémát jelenthet, hogy „stroke”-on sok helyen csak az agyi, ischaemiás eredetű kórképeket értik, ami a betegségek beosztásában zavaró tényezőt jelenthet, és a leírtak esetlegesen deformálhatják a forrásadatokat [25].

Vizsgálatunk erőssége a standardizált cerebrovascularis halálozás átfogó elemzése 42 ország tekintetében a 45-59 éves korcsoportban.

Eredményeink tükrében elmondható, hogy mind a férfiak, mind pedig a nók cerebrovascularis betegségekből eredő, korspecifikus halálozása a nyugat-európai országokban volt a legalacsonyabb, míg a legmagasabb a Szovjetunió utódállamaiban. A területi egyenlőtlenség magyarázható többek között az akut stroke ellátásának gyorsabb ütemú fejlődésével a fejlett országokban [26, 27]. A kedvezőtlenebb korai halálozás oka kereshető a primer prevenció hiányosságában, a betegek súlyosabb állapotában, a diagnózis késői felismerésében egyaránt [22, 28]. A magyarországi stroke-ellátás szempontjából is örömteli, hogy Magyarországon a nyugat-európai átlagnál jobban, 62,2\%-kal csökkent a férfiak és 59,1\%-kal a nők cerebrovascularis halálozása 1990 és 2014 között.

Összességében a teljes vizsgálati periódus alatt javult a korspecifikus, cerebrovascularis halálozás valamennyi vizsgált régióban és országban, hasonlóan más tanulmányban leírtakhoz [29]. Az elemzett időszakon belül a legmarkánsabb, több mint 20\%-os növekedést a Szovjetunió utódállamainak esetében találtuk az 1990-es évek első felében mindkét nem tekintetében, aminek hátterében állhat a rendszerváltozást követő gazdasági visszaesés, valamint a politikai és társadalmi hatások. Az említett régióban az ezredfordulót követően is növekedett még helyenként a cerebrovascularis halálozás a 45-59 éves korcsoportban, a nyugat-európai és kelet-európai országokkal ellentétben, ahol az 1990-es évek végétól szinte folyamatosan csökkent, részben hasonló tendenciát mutatva a témában végzett, eltérő korcsoportban készített más kutatásokkal [1, 30-32]. Elemzéseink eredményeit támasztja alá Vargáné és Ádány 1970 és 1997 között végzett, a keringési rendszeri betegségekből eredő halálozás trendjeit Magyarországon és az Európai Unió akkori országaiban vizsgáló kutatása is, miszerint a saját elemzési periódusunkat részlegesen átfedő (19701997) időszakban az 1990-es évek elején a cerebrovascularis betegségekből eredő, korai halálozás kockázatának emelkedését tapasztalták [33]. Eredményeink szerint a kelet-európai országok korspecifikus cerebrovascularis halálozása nem különbözött szignifikánsan a Szovjetunió utódállamaitól egyik nem tekintetében sem a vizsgált években $(1990,2004,2014)$. A Szovjetunió utódállamainak és a kelet-európai országoknak a halálozásában a rendszerváltozás után bekövetkezett változások egyes országokban összefüggést mutatnak a GDP változásával és a jövedelmi egyenlőtlenségekkel is $[34,35]$. Szốcs és $m$ tsai is igazolták elemzésükben a cerebrovascularis betegségek és a szocioökonómiai helyzet összefüggését Magyarországon [36]. A cerebrovascularis halálozás vizsgálati periódusunkon belüli jelzett, átmeneti növekedéséhez hozzájárulhatott az érintett időszakban a cardiovascularis rizikófaktorok emelkedése is [37]. A Szovjetunió utódállamai közül a teljes vizsgált periódusban Kirgizisztánban csökkent a legkisebb mértékben a nők és a férfiak korspecifikus, cerebrovascularis halálozása, és itt volt a legmagasabb is $(1990,2004,2014)$ más kutatáshoz hasonlóan [27]; Kirgizisztánban a dohányzás kiemelkedően magas prevalenciája szerepet játszhat a kedvezőtlen halálozási mutatókban [38].

Eredményeink szerint a kelet-európai országokat tekintve 2004-ben és 2014-ben mindkét nemben Bulgáriában volt a legmagasabb a 45-59 éves korcsoportban az agyi érrendszeri betegségekből eredő halálozás; hasonló tendenciát mutat az idő előtti halálozás tekintetében végzett más vizsgálat is [29]. Bulgáriában Kirgizisztánhoz hasonlóan szintén magas a dohányzás prevalenciája [38]. Nyugat-Európán belül Levi és mtsai kutatásához [23] hasonlóan jelentős különbségeket találtunk; a teljes vizsgálati periódusunkat tekintve Luxemburg esetében javult mindkét nemben a legnagyobb mértékben a korspecifikus, cerebrovascularis halálozás [29]. Elemzésünk szerint a vizsgált régiók országait együttesen nézve a 45-59 éves férfiak körében Luxemburgot követően Észtországban csökkent a legjelentősebben a cerebrovascularis halálozás; eredményeinkhez hasonlóan kedvező változásról számol be egy korábbi kutatás is [39].

A kelet-európai országokban és a szovjet utódállamokban az 1990 utáni gazdasági és finanszírozási változások jelentős hatást gyakoroltak az egészségügyi rendszerek múködésére [40-45] és benne a neurológiai ellátásokra $[46,47]$.

A nemek vonatkozásában elmondhatjuk, hogy a 4559 éves nók cerebrovascularis halálozása kedvezőbb, ami összefüggést mutathat többek között a betegség kialakulása szempontjából protektív tényezőnek számító ösztrogénnel [9]. További okként említhető, hogy a férfiak körében magasabb a dohányzás és az alkoholfogyasztás prevalenciája $[48,49]$. A férfiak idő előtti halálozásának okaival Koppés mtsa is foglalkozott kutatásában: eredményeik szerint a férfiak esetében a korai halálozás szignifikáns előrejelzője többek között az alacsony iskolai végzettség, az alacsony társadalmi helyzet, az alacsony jövedelem, a biztos foglalkoztatottság hiánya, a depreszszió és a társas támogatottság hiánya egyaránt. A kutatók ezeket a stresszt kiváltó tényezőket a nők esetében nem tudták kimutatni. A magyar férfiak korai halálozásának 
kedvezőtlen mutatóinak javításához a megelőzés hálózatának múködtetése szükségszerú, beleértve iskolai, munkahelyi és közösségi prevenciós programokat egyaránt [50].

A munkaképes korú felnőttek körében a cerebrovascularis betegségek kockázati tényezőinek megelőzése csökkentheti a rokkantságot, a társadalmi egészségügyi ellátás költségeit, és hozzájárul az életminőség javulásához [30].

A cerebrovascularis betegségekból eredő halálozás csökkentéséhez elengedhetetlen a prevenciós technikák szorgalmazása a rizikófaktorok befolyásolására irányulóan.

Anyagi támogatás: A közlemény az Innovációs és Technológiai Minisztérium ÚNKP-19-3-I-PTE-398. kódszámú Új Nemzeti Kiválóság Programjának (N. N.), valamint a Pécsi Tudományegyetem Tématerületi Kiválósági Program 2019 (TUDFO/51757-1/2019-ITM) és a Felsőoktatási Intézményi Kiválósági Program 2019 (20765-3/2018/FEKUTSTRAT) támogatásával (E. D., Cs. T., P. R., B. I.) készültt.

Szerzôi munkamegosztás: A vizsgálat tervezése: N. N., Endrei D., B. I., Sz. L. Irodalomkutatás: N. N., H. L., Endrei D, Elmer D., P. R. Adatgyújtés: N. N., Endrei D., B. I. Statisztikai elemzések: N. N., Cs. T., B. I. A kézirat megszövegezése: N. N., Endrei D., H. L., Elmer D., Cs. T., P. R., Sz. L., B. I. A cikk végleges változatát valamennyi szerző elolvasta és jóváhagyta.

Érdekeltségek: A szerzőknek nincsenek érdekeltségeik.

\section{Irodalom}

[1] Tong X, Yang Q, Ritchey MD, et al. The burden of cerebrovascular disease in the United States. Prev Chronic Dis. 2019; 16: 180411 .

[2] Gulácsi L, Májer I, Kárpáti K, et al. Mortality of hospitalized stroke patients in Hungary, 2003-2005. [A hospitalizált stroke betegek halálozása Magyarországon, 2003-2005.] Ideggyógy Szle. 2007; 60: 321-328. [Hungarian]

[3] Oberfrank F, Donka-Verebes É, Boncz I. Health insurance cost of stroke in Hungary: a cost of illness study. Value Health 2016 19: A649.

[4] Kárpáti K, Májer I, Boncz I, et al. Social insurance costs of hospital treatment of stroke in Hungary, 2003-2005. [A stroke kórházi ellátásának egészségbiztosítási költségei Magyarországon, 2003-2005.] Ideggyógy Szle. 2007; 60: 311-320. [Hungarian]

[5] Fehér G. The positive additive effect of rosuvastatin on platelet aggregation parameters in patients with cerebrovascular disease. [A rosuvastatin kedvező additív hatása a thrombocyta-aggregációs paraméterekre cerebrovascularis betegek esetében.] Lege Artis Med. 2015; 25: 517-521. [Hungarian]

[6] GBD 2016 Stroke Collaborators. Global, regional, and national burden of stroke, 1990-2016: a systematic analysis for the Global Burden of Disease Study 2016. Lancet Neurol. 2019; 18: 439458 .
[7] European Heart Network. European Cardiovascular Disease Statistics 2017. Available from: http://www.ehnheart.org/cvdstatistics/cvd-statistics-2017.html [accessed: June 10, 2020].

[8] Gózon Á. 2015 the year of stroke prevention. One in six people worldwide will have a stroke in their lifetime. [2015 a stroke megelőzésének éve. Minden hatodik ember szenved el gutaütést.] Élet Tud. 2015; 70: 915. [Hungarian]

[9] Zhang C, Lan T, Zhe Y, et al. Epidemiology investigation of stroke among Mongolian and Han population aged over 45 in Inner Mongolia. Sci Rep. 2017; 7: 45710.

[10] Lovadi E, Csécsei P, Lovig Cs, et al. Lipids and cerebrovascular disease - New therapeutic options in lowering LDL-cholesterol. [Lipidek és az agyérbetegség - Új lehetôségek az LDL-koleszterin-szint csökkentésére.] Orv Hetil. 2016; 157: 2059-2065. [Hungarian]

[11] Asplund K, Bonita R, Kuulasmaa K. WHO MONICA Project. A worldwide monitoring system for cardiovascular diseases: cardiovascular mortality and risk factors in selected communities. World Health Statistics Annual 1989; 27-149.

[12] Márk L. Stroke prevention in the elderly: Effectiveness and safety of edoxaban in elderly patients according to the results of the ENGAGE AF study. [Stroke-prevenció időskorban: az edoxabán hatékonysága és biztonságossága idős betegekben az ENGAGE AF vizsgálat eredményei alapján.] Orv Hetil. 2018; 159: 798802. [Hungarian]

[13] Masszi G. The role of new oral anticoagulants in stroke prevention in patients suffering from atrial fibrillation. [Az új típusú orális antikoagulánsok szerepe a pitvarfibrillációban szenvedő betegek stroke-prevenciójában.] Háziorv Továbbk Szle. 2017; 22: 371-375. [Hungarian]

[14] Csécsei P, Várnai R, Nagy L, et al. L-arginine pathway metabolites can discriminate paroxysmal from permanent atrial fibrillation in acute ischemic stroke. [Az L-arginin-útvonal metabolitjai differenciálhatják a paroxysmalis pitvarfibrillációt a permanenstől akut ischaemiás stroke-ban.] Ideggyógy Szle. 2019; 72: 79-88. [Hungarian]

[15] Szapáry L. New treatment option for oral anticoagulation in the prevention of cardiogenic stroke. Focus on the RE-LY trial. [Az orális antikoagulálás új lehetősége a kardiogén eredetû stroke prevenciójában. Fókuszban a RE-LY vizsgálat.] Lege Artis Med. 2011; 21: 177-184. [Hungarian]

[16] Pandian JD, Gall SL, Kate MP, et al. Prevention of stroke: a global perspective. Lancet 2018; 392: 1269-1278.

[17] Zsuga J, Gesztelyi R, Kemény-Beke A, et al. Different effect of hyperglycemia on stroke outcome in non-diabetic and diabetic patients - a cohort study. Neurol Res. 2012; 34: 72-79.

[18] Powers WJ, Rabinstein AA, Ackerson T, et al. Guidelines for the early management of patients with acute ischemic stroke: 2019 update to the 2018 guidelines for the early management of acute ischemic stroke: a guideline for healthcare professionals from the American Heart Association/American Stroke Association. Stroke 2019; 50: e344-e418.

[19] Mirolovics Á, Bokor M, Dobi B, et al. Notification strategy and predictors of outcome in stroke ineligible for reperfusion therapies. Front Neurol. 2019; 10: 1060.

[20] Nagy Z, Vassányi I, Óváry Cs, et al. Advances in stroke care, has Hungary taken steps forward? An overview of the achievements of the past 25 years. [Léptünk-e előre a hazai stroke-beteg ellátásban? Áttekintés az elmúlt 25 év törekvéseirôl.] IME 2019; 18(6): 49-53. [Hungarian]

[21] Asplund K, Bonita R, Kuulasmaa K, et al. Multinational comparisons of stroke epidemiology. Evaluation of case ascertainment in the WHO MONICA stroke study. World Health Organization Monitoring Trends and Determinants in Cardiovascular Disease. Stroke 1995; 26: 355-360.

[22] Szőcs I, Bereczki D, Belicza É. Results of stroke care in Hungary in the frame of international comparison. [A stroke-ellátás hazai 
eredményei a nemzetközi adatok tükrében.] Orv Hetil. 2016; 157: 1635-1641. [Hungarian]

[23] Levi F, Chatenoud L, Bertuccio P, et al. Mortality from cardiovascular and cerebrovascular diseases in Europe and other areas of the world: an update. Eur J Cardiovasc. Prev. Rehabil. 2009; 16: $333-350$.

[24] Németh N, Elmer D, Horváth L, et al. Age-specific examination of early cerebrovascular mortality 1990-2014. Value Health 2020; 23 (Suppl 1): S100.

[25] Szirmai I. (ed.) Neurology. [Neurológia.] Medicina Könyvkiadó, Budapest, 2011. [Hungarian]

[26] Bennett DA, Krishnamurthi RV, Barker-Collo S, et al. The global burden of ischemic stroke: findings of the GBD 2010 study. Glob Heart 2014; 9: 107-112.

[27] Ilic I, Ilic M, Sipetic Grujicic S. Trends in cerebrovascular diseases mortality in Serbia, 1997-2016: a nationwide descriptive study. BMJ Open 2019; 9: e024417.

[28] Boromisza P, Nagy Z, Szikora I. Milestones in the treatment of acute stroke. Interview with Prof. Dr. Zoltán Nagy and Dr. István Szikora. [Mérföldkövek az akut stroke ellátásában. Interjú Prof. Dr. Nagy Zoltánnal és Dr. Szikora Istvánnal.] IME 2017; 16(9): 44-47. [Hungarian]

[29] Megyesiova S, Lieskovska V. Premature mortality for chronic diseases in the EU member states. Int J Environ Res Public Health 2019; 16: 4021

[30] George MG, Tong X, Bowman BA. Prevalence of cardiovascular risk factors and strokes in younger adults. JAMA Neurol. 2017 74: 695-703.

[31] Levi F, Lucchini F, Negri E, et al. Trends in mortality from cardiovascular and cerebrovascular diseases in Europe and other areas of the world. Heart 2002; 88: 119-124.

[32] Carlson P. The european health divide: a matter of financial or social capital? Soc Sci Med. 2004; 59: 1985-1992.

[33] Vargáné HP, Ádány R. Trends of premature mortality from cardiovascular diseases in Hungary and the European Union, 1970-1997. [A keringési rendszer betegségei okozta korai halálozás trendjei Magyarországon és az Európai Unióban, 19701997.] Orv Hetil. 2000; 141: 601-607. [Hungarian]

[34] Boncz I, Sebestyén A. Economy and mortality in Eastern and Western Europe between 1945 and 1990: the largest medical trial of history. Int J Epidemiol. 2006; 35: 796-797. [Erratum: Int J Epidemiol. 2007; 36: 261-262.]

[35] Marmot M, Bobak M. International comparators and poverty and health in Europe. BMJ 2000; 321: 1124-1128.

[36] Szőcs I, Bereczki D, Ajtay A, et al. Socioeconomic gap between neighborhoods of Budapest: striking impact on stroke and possible explanations. PLoS ONE 2019; 14: e0212519.

[37] Nichols M, Townsend N, Scarborough P, et al. Trends in agespecific coronary heart disease mortality in the European Union over three decades: 1980-2009. Eur Heart J. 2013; 34: 30173027.

[38] World Health Organization. Tobacco control policies and interventions, 2014. Monitoring tobacco use and prevention policies.
WHO, Geneva. Available from: http://gamapserver.who.int/ gho/interactive_charts/tobacco/use/atlas.html [accessed: June $18,2020]$.

[39] Rahu K, Rahu M, Zeeb H. Sex disparities in premature adult mortality in Estonia 1995-2016: a national register-based study. BMJ Open 2019; 9: e026210.

[40] Boncz I, Sebestyén A. Financial deficits in the health services of the UK and Hungary. Lancet 2006; 368: 917-918.

[41] Endrei D, Molics B, Ágoston I. Multicriteria decision analysis in the reimbursement of new medical technologies: real-world experiences from Hungary. Value Health 2014; 17: 487-489.

[42] Boncz I, Nagy J, Sebestyén A, et al. Financing of health care services in Hungary. Eur J Health Econ. 2004; 5: 252-258.

[43] Betlehem J, Horváth A, Jeges S, et al. How healthy are ambulance personnel in Central Europe? Eval Health Prof. 2014; 37 : 394-406.

[44] Boncz I, Evetovits T, Dózsa Cs, et al. The Hungarian Care Managing Organization Pilot Program. Value Health Reg Issues $2015 ; 7: 27-33$.

[45] Molics B, Boncz I, Leidecker E, et al. Health insurance aspects of physiotherapeutic care of neurology disorders in outpatient care. [A neurológiai kórképek fizioterápiás ellátásának egészségbiztosítási vonatkozásai a járóbeteg-szakellátásban.] Ideggyógy Szle. 2015; 68: 399-408. [Hungarian]

[46] Bereczki D, Ajtai A. Neurology 2009: a survey of Hungarian neurology capacities, their utilization and of neurologists, based on 2009 institutional reports in Hungary. [Neurológia 2009: helyzetfelmérés a magyarországi neurológiai kapacitásokról, azok kihasználtságáról és a szakorvosokról a 2009-es intézményi jelentések alapján.] Ideggyógy Szle. 2011; 64: 173-185. [Hungarian]

[47] Bereczki D, Csiba L, Komoly S, et al. The carrier model of neurology in Hungary: a proposal for the solution until 2020. [A neurológia magyarországi (élet-) pályamodellje - megoldási javaslat 2020-ig.] Ideggyógy Szle. 2011; 64: 377-384. [Hungarian]

[48] Kuhrs E, Winkler V, Becher H. Risk factors for cardiovascular and cerebrovascular diseases among ethnic Germans from the former Soviet Union: results of a nested case-control study. BMC Public Health 2012, 12: 190.

[49] Barker-Collo S, Bennett DA, Krishnamurthi RV, et al. Sex differences in stroke incidence, prevalence, mortality and disabilityadjusted life years: results from the global burden of disease study 2013. Neuroepidemiology 2015; 45: 203-214.

[50] Kopp M, Skrabski Á. Why do Hungarian men die early? [Miért halnak meg idő előtt a magyar férfiak?] Neuropsychopharmacol Hung. 2009; 11: 141-149. [Hungarian]

(Németh Noémi,

Pécs, Vörösmarty u. 3., 7621 e-mail: noemi.nemeth@etk.pte.hu)

A cikk a Creative Commons Attribution 4.0 International License (https://creativecommons.org/licenses/by/4.0/) feltételei szerint publikált Open Access közlemény, melynek szellemében a cikk bármilyen médiumban szabadon felhasználható, megosztható és újraközölhetö, feltéve, hogy az eredeti szerző és a közlés helye, illetve a CC License linkje és az esetlegesen végrehajtott módosítások feltüntetésre kerülnek. (SID_1) 